\title{
新粘弾性材料モデルに基づく非線形構成式の定式化*
}

\author{
Heinz-Josef PENKALLA*1，菊 地 賢 司*2
}

\section{Inelastic Constitutive Equation Based on a New Viscoelastic Material Model}

\author{
Heinz Josef PENKALLA and Kenji KIKUCHI
}

\begin{abstract}
A new viscoelastic material model was developed to describe deformations under various loads at the high temperature creep regime. In the model the inelastic strain rate is written in the form of at flow equation of the Norton Bailey type and the material hardening during deformation under various loads is induced by an internal stress which is subdivided into back stress and friction stress. The back stress represents a conservative part of the creep resistance while the friction stress includes all the dissipative parts in the internal structure such as grain boundary sliding, diffusion and interaction between dislocation and precipitation. An inelastic constitutive equation is estab. lished based on the new viscoelastic material model. A case study was done for Hastelloy XR, a $\mathrm{Ni}$ based superalloy. Deformation analyses show a good agreement between calculations and ex. perimental results for creep, relaxation. tensile and stress dip tests.
\end{abstract}

Key Words: Constitutive Equation, Creep, Viscoelasticity, Inelasticity, Internal Stress, Back Stress, Friction Stress, Hastelloy XR, Relaxation, Stress I)ip

\section{1. 緒言}

\section{クリーナ゙变形領域に扔ける耐熱金属材料の间温変形} 解析では，クリーブひずみ，忍力，侍間の関係を表す

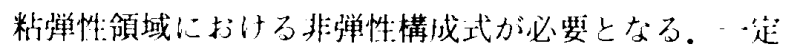
忍力条件のクリーブ变形の埸命には、変形性線は…次

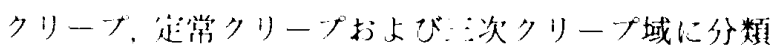

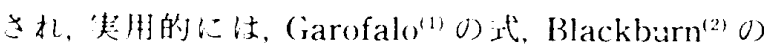

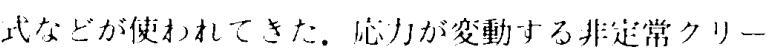

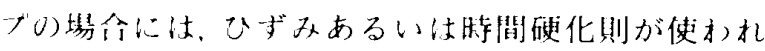

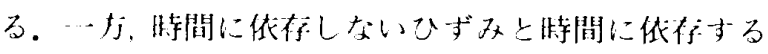
ひずみを放しない統一形の構成式では，流れ則と発

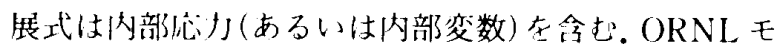

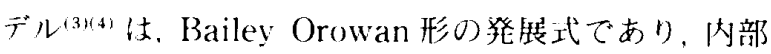
念少の発展は硬化と吅復项より構成される。しかし， ORNL モデルでは，流机則に含まれるKが柱けに依 仔しない定数となっているため，必力がK以トでは

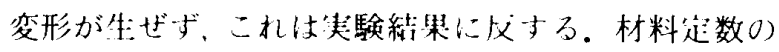

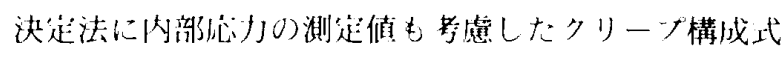
は，打活・武滕ら(5)も起式化した。ただし，材料走数の

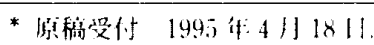

* Forschungszentrum Jülich Cimbl1, KFA (GERMAVY)

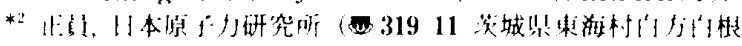
$24)$.
決运には，内部心力を測定しなけ机ばならない。

$$
\text { クリーフ変形にも適朋できる統一形の構成式として }
$$

は、ほかにChaboche モデル(6). Miller モデル(7)， Krempl モデル(x)，村1:大野モデル(9)抄よび大野モデ ルは1などが提案されているが、これらは粘塑性の棈 成式に対念する。

構成式り作成に際しては，材料足数の決定法の複雑 さが指摘いされているが，本論文で盗式化するクり 一フ構成式では、材料分数をクリープ变形曲線より決

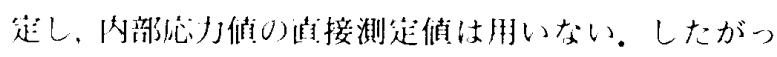
て、材料等数の决定法が明り上うで再現性がある。ま た，しきい储 $K$ 在必要としないので尖験事果も説明 しうる。以トに，ハステロイXRを例にして，それら の決仚法を説明寸る。さにに，本モデルの有效性を証

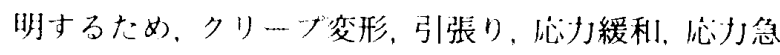
城に刘求る类験結果と比較する。

\section{2. 新粘弾性材料モデル}

新粘弹性材料モデルは，非弾性ひずみ速度 $\dot{\varepsilon}_{\text {In }}$ を内 部必力を含むNorton Bailey 形(121の心゙き乗則で表

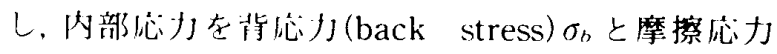

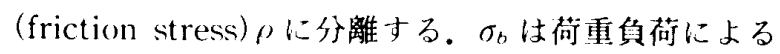
誘起必小で，クリーナ変形抵抗の保存力である。 
クリープ変形抵抗の散逸力であり、粒界す心゙り、抬散

機構、転位の運動，析出物に起因すると考えられる。

$$
\begin{aligned}
& \dot{\varepsilon}_{\text {in }}=K\left(\sigma-\sigma_{i}\right)^{v} \\
& \sigma_{i}=\sigma_{b}+\rho \cdots \cdots
\end{aligned}
$$

転位密度に依存する $\sigma_{b}$ は, 密度の増加とともに大き

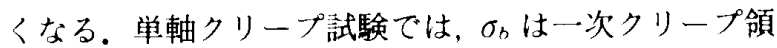

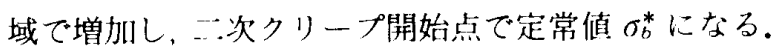
背応力の速度は現在值 $\sigma_{b}$ と $\sigma_{b}^{*} の$ 差，並びにひずみ速 度 $\dot{\varepsilon}^{*}$ に独立に比例すると仮起する [式(3)].

$$
\dot{\sigma}_{b}=\lambda \dot{\varepsilon}^{*}\left(\sigma_{b}^{*}-\sigma_{b}\right)
$$

$\dot{\varepsilon}^{*}$ はクリーナ゙ひずみ硬化則の場合には $\dot{\varepsilon}_{\text {in }}$ (非弾性ク リーブひずみ速度)，また全ひずみ硬化則では它 tot (全 ひずみ速度)となる。ある傎荷応力に对する保存力と散 逸力を，ハラメー夕れ。を用いた式(4)により定義し 内部伈少 $\sigma_{i}$ と関連づける。

$$
\left.\begin{array}{l}
\sigma_{b}=\left(1-q_{o}\right) \sigma_{i} \\
\rho=q_{o} \sigma_{i}
\end{array}\right\}
$$

qoはクリープ変形抵抗に扔ける保存力と散逸力の分 配比を表す。クリープの变形機構は応力に依存して変 化し，低灿少では粒界㧓散クリープ，高忍力では転位。 クリープ機構となる。したがって, 高応力では保存力

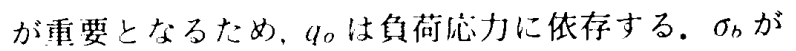
$\sigma_{b}^{*}$ に到達すると，内部忍力毛定常值 $\sigma_{i}^{*}$ になる。

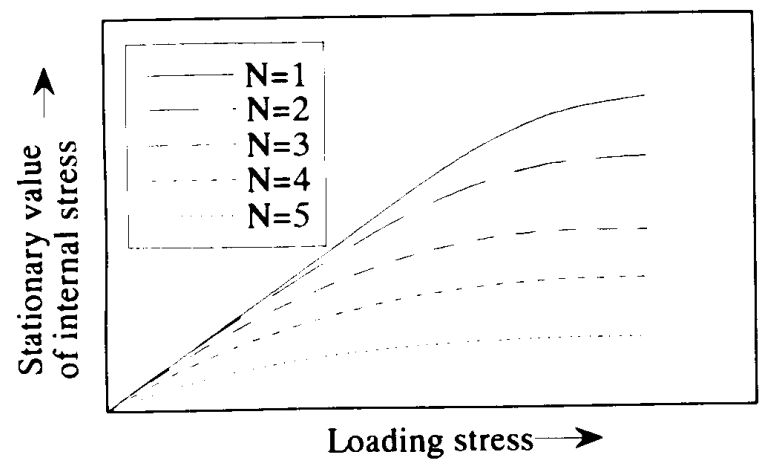

Fig. 1 Stationary value of internal stress induced by loading stress

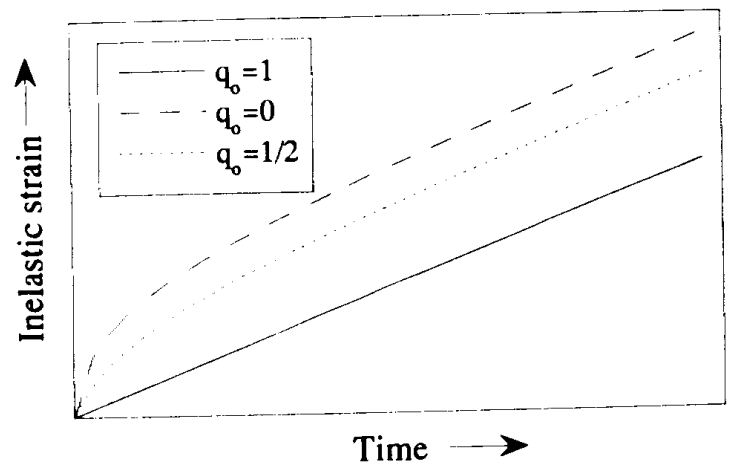

Fig. 2 The effect of parameter $q_{0}$

$$
\sigma_{b}^{*}=\left(1-q_{0}\right) \sigma_{i}^{*}
$$

このとき, 非弾性ひずみ速度は最小クリープひずみ速 度 $\dot{\varepsilon}_{\min }$ となる。 $\dot{\varepsilon}_{\min }$ を例えば式(5)で与えると $\sigma_{i}^{*}$ は 式(6)で表される。

$$
\begin{aligned}
& \dot{\varepsilon}_{\mathrm{m} \ln }=A \sigma^{m} \exp \left(\alpha \sigma^{\beta}\right) \\
& \sigma_{i}^{*}=\sigma-(A / K)^{1 / N} \sigma^{m} \exp \left\{(\alpha / N) \sigma^{\beta}\right\}
\end{aligned}
$$

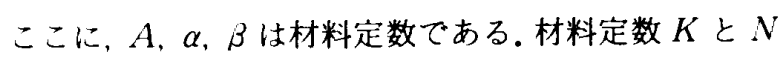
を決定するには，次の二つの境界条件が考えられる。

$$
\begin{aligned}
& \text { (I) } \frac{d \sigma_{i}^{*}}{d \sigma}=0, \quad \sigma \geq \sigma_{y} \\
& \text { (II) } \frac{d \sigma_{i}^{*}}{d \sigma}=\max , \quad \sigma=0
\end{aligned}
$$

境界条件 I は, 降伏応力 $\sigma_{y}$ 以上の応力では内部芯 力の定常值 $\sigma_{i}^{*}$ は増加しないことを意味する。境界条 件IIは式(5)の形に依存し，常に淦たされるとは限ら ない.

\section{3. パラメータの特性}

$K$ とNの值は最小クリープひずみ速度を与える. 境界条件 I を満たす $N$ に対する内部応力の定常值の 举動例を図 1 に示方.

摩擦忍力の值に対伈するパラメータ $q_{0}$ は一次クリ ープの硬化則を規定する，q。は，内部忍力に含まれる 保存力と散逸力の比率を定めるだけであり，保存力の

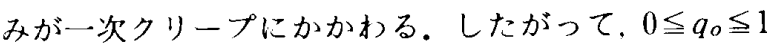
であり， $q_{o}=1$ では一次クリープは生じず, $q_{o}=0$ で は保存力の寄与が最大となる(図 2).

最小クリープ速度の値と一次クリープの期間は，qo の影響を受けない。これに対し，パラメータネは一次 クリープの期間, あるいは一次クリープ中のひずみ量 に影響する。図 3 に $q_{o}=0$ のときの入の影響を示す。 $\lambda$ は間接的に $K$ と $N$ の值に依存しているので，qoは iの前に定める必要がある.

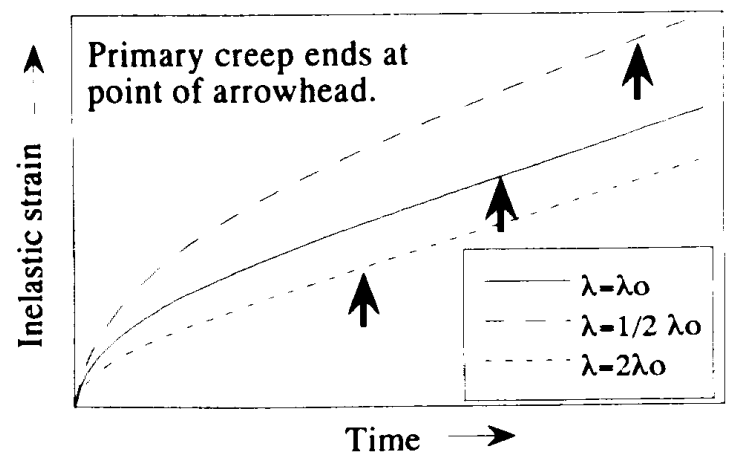

Fig. 3 The effect of parameter $\lambda$ 


\section{4. ハステロイXRの \\ 非弾性權成式の定式化}

以下に新粘弾性材料モデルを用いてハステロイ XR の非弾性構成式を定式化する。使用するデータは $850^{\circ} \mathrm{C}$ 定応力クリープ実験から得た変形特性(13) のう ち, 初期非弾性ひずみ速度, 最小クリープひずみ速度 拉よび一次クリープの期間である。これらは，定常ク リープに対するGarofaloの式を導出する際にも必要 なデータである。降伏応才，ヤング率は引張試験また は低サイクル疲労試験などより求めることができる (表 1).

最小クリープひずみ速度はNorton 則 $\left(\dot{\varepsilon}=A \sigma^{m}\right)$ で記述できるので，境界条件 I より $K$ と $N$ の関係が 式（７）で去えられる。

$$
K=A\left(\cdot \frac{m}{N}\right)^{-N} \sigma^{m-N}
$$

予加エああいは応力履歴のない材料では，時刻零で $\sigma_{b}=0$ となり, 内部応力は散逸力 $\rho$ だととる。非弾 性ひずみ速度の初期值 $\dot{\varepsilon}_{\text {init }}$ は, 式(8)で記述できる ので，式(4)を考虑して $q_{0}$ は式 (9)となる.

Table 1 Material properties in Hastelloy XR $\left(850^{\circ} \mathrm{C}\right)$

\begin{tabular}{|c|c|c|c|c|}
\hline Creep: & $\sigma(\mathrm{MPa})$ & $\dot{\varepsilon}_{\text {init }}\left(h^{-1}\right)$ & $\dot{\varepsilon}_{\min }\left(h^{-1}\right)$ & $t_{p}(h)$ \\
\hline & 58 & $1.186 \times 10^{-4}$ & $8.00 \times 10^{-5}$ & 1250 \\
\hline & 90 & $4.155 \times 10^{-3}$ & $1.95 \times 10^{-3}$ & 90 \\
\hline & 120 & $1.845 \times 10^{-2}$ & $9.65 \times 10^{-3}$ & 20 \\
\hline & 170 & $1.342 \times 10^{-1}$ & $7.60 \times 10^{-2}$ & 3.5 \\
\hline & 200 & $3.534 \times 10^{-1}$ & $2.25 \times 10^{-1}$ & 1.0 \\
\hline & 250 & 1.131 & $7.50 \times 10^{-1}$ & 0.35 \\
\hline
\end{tabular}

Others: $\quad \sigma_{y}=236 \mathrm{MPa}, \mathrm{E}=135.4(\mathrm{GPa})$

Note: $\sigma=$ stress, $\dot{\varepsilon}=$ creep strain rate, $\dot{\varepsilon}_{\text {int }}=$ initial inelastic strain rate, $\dot{\varepsilon}_{\text {min }}=$ minimum creep strain rate, $t_{p}=$ duration of primary creep, $\sigma_{y}=$ yield stress, $E=$ Young's modulus.

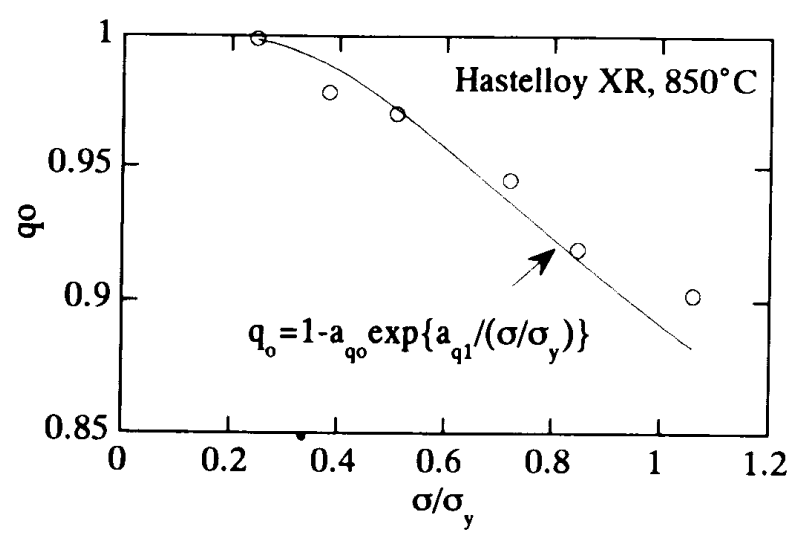

Fig. 4 Parameter $q_{o}$ vs. normalized stress $\sigma / \sigma_{y}$

$$
\begin{gathered}
\dot{\varepsilon}_{\text {init }}=K(\sigma-\rho)^{N} \ldots \\
q_{0}=-\left(\frac{\dot{\varepsilon}_{\text {init }}}{\frac{K}{K}}\right)^{1 / N} \\
\sigma_{i}^{*}
\end{gathered}
$$

無次元仝力 (伈力/降伏㐫力) と $q_{0}$ の関係(図 4)上り, $q_{o}=g(\sigma)$ の関数形を考察して, 式(10)を得た。

$$
g(\sigma)=1-a_{q 0} \exp \left(\frac{a_{q 1}}{X}\right)
$$

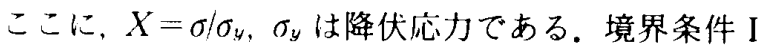
を満たすすべての $N$ と $K$ の值 $(1 \leqq N \leqq m)$ より最適 值を決定する方法を考察して， $\sigma_{b, \text { off }}$ の二乗の総和 $F$ を最小にする条件とした。ここに，店, of めたある $N$ に対する $q_{0}$ の值 $q_{o, N}$ と式(10)で近似し た $q_{\circ}$ の值 $q_{o}$, intより計算される。

$$
\begin{aligned}
& F=\sum \sigma_{b, \text { orf }}^{2} \\
& \sigma_{b, \text { off }}=\left\{\left(1-q_{o, \text { int }}\right)-\left(1-q_{o, N}\right)\right\} \sigma_{i}^{*}
\end{aligned}
$$

一次クリープの期間は，背応力の発展式(3)の $\lambda に$ 関連する。夹験で定まる一次クリープ期間に対応する $\lambda$ を数值計算で求めた後(図 5$), \lambda=h(\sigma)$ の関数形を 考察し式(12)を定めた。入はq。には似存しない.

$$
h(\sigma)=a_{\lambda 0} \exp \left(a_{\lambda 1} \sigma+a_{\lambda 2} \sigma^{2}\right)
$$

決定した 9 個 $(\alpha, \beta$ 在除けば尖質的に 7 個) の末知 数を以トに亦す。

$$
\begin{aligned}
& N=1.8 \\
& K=2.8955 \times 10^{-4} \\
& a_{q 0}=0.4393 \\
& a_{q 1}=-1.3956 \\
& a_{\lambda 0}=12.2603 \\
& a_{\lambda 1}=6.4759 \times 10^{-4} \\
& a_{\lambda 2}=-2.0028 \times 10^{-5} \\
& \alpha=0 \\
& \beta=0
\end{aligned}
$$

負荷荷重に対忍する内部忍力，摩摖応力および背応 力の定常值を図 6 に示す。

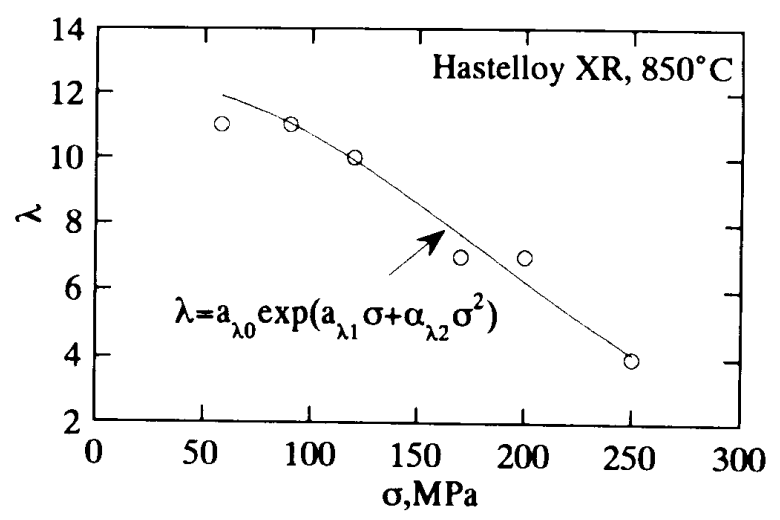

Fig. 5 Parameter $\lambda$ vs. stress $\sigma$ 


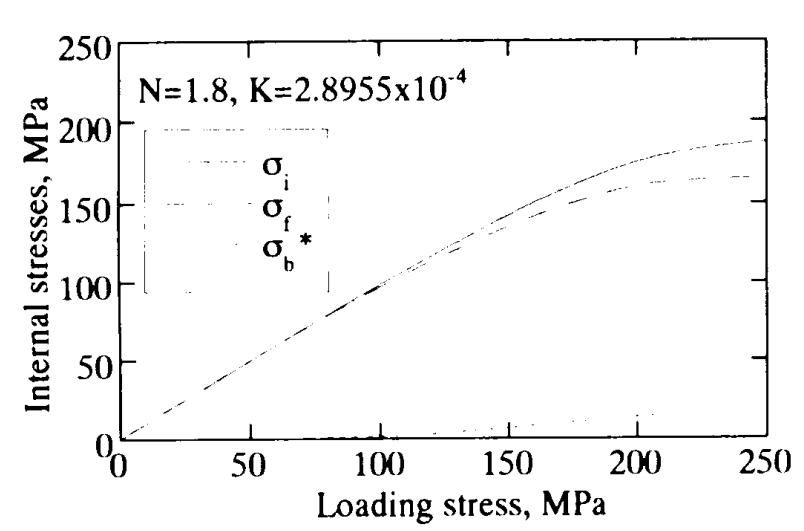

Fig. 6 Internal stresses vs. loading stress

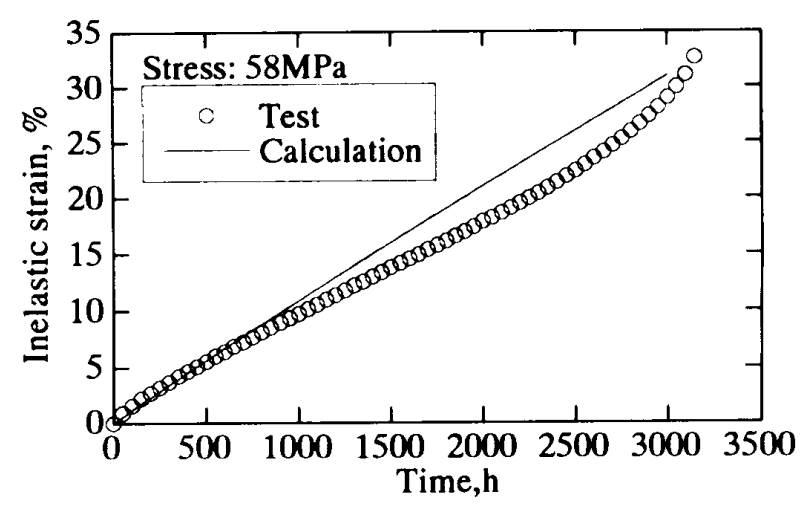

(a) Stress is $58 . \mathrm{MPa}$

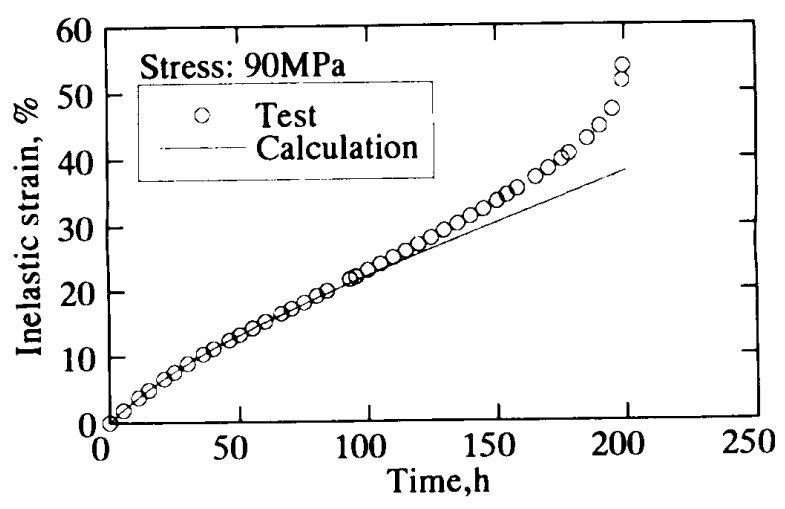

(b) Stress is $90 \mathrm{MPa}$

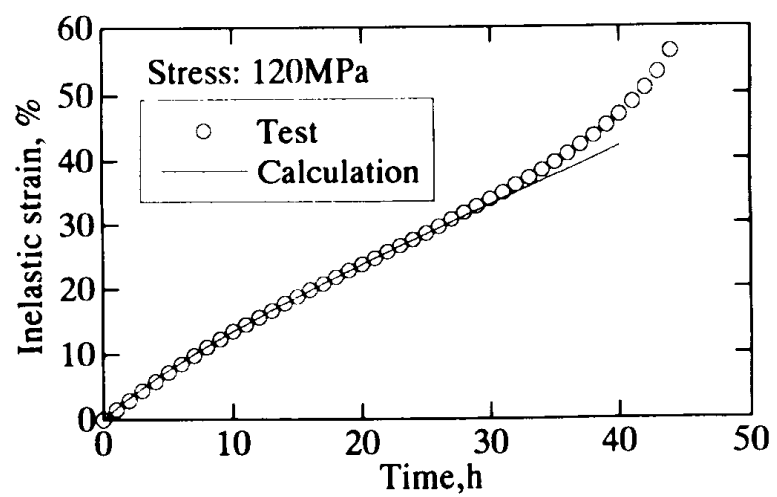

(c) Stress is $120 \mathrm{MPa}$
荷重負荷形式に対応した芯力、ひずみの変形挙動は 次のように表される。

\section{クリープ変形}

定応力の場合

$$
\dot{\varepsilon}_{t o t}=\dot{\varepsilon}_{i n}=K\left\{\sigma-\left(\sigma_{b}+\rho\right)\right\}^{N}
$$

定荷重の場合 $\left(\sigma_{0}:\right.$ 初期応力)

$$
\dot{\varepsilon}_{\text {tot }}=K\left\{\frac{\sigma_{0} \exp \left(\varepsilon_{\text {in }}\right)}{E}+1\right\}\left\{\sigma-\left(\sigma_{b}+\rho\right)\right\}^{N} \ldots
$$

応力緩和の場合

$$
\dot{\sigma}=-E K\left\{\sigma-\left(\sigma_{b}+\rho\right)\right\}^{N}
$$

引張変形 (全ひずみ速度一定)

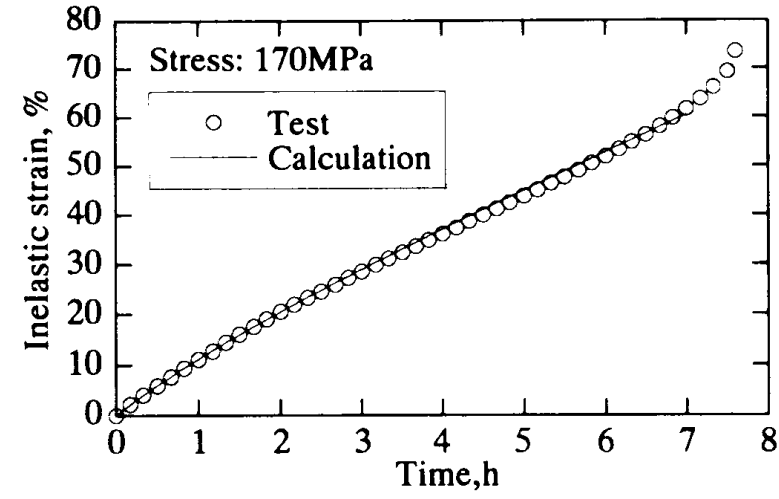

(d) Stres is $170 \mathrm{MPa}$

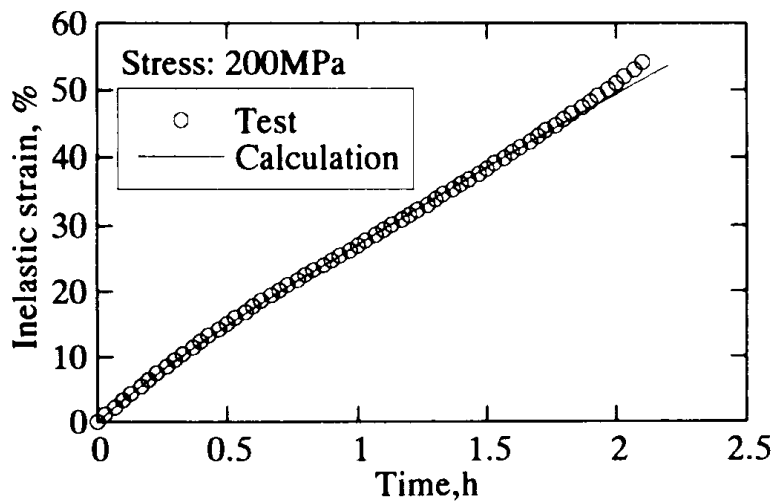

(e) Stress is $200 \mathrm{MPa}$

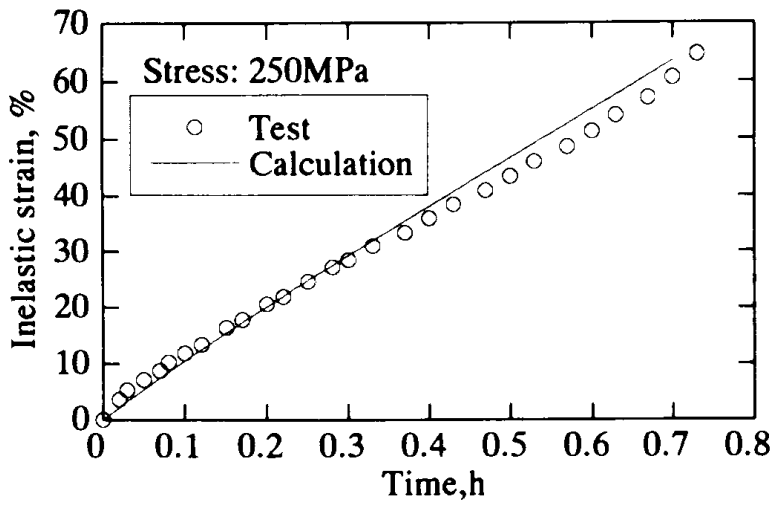

(f) Stress is $250 \mathrm{MPa}$

Fig. 7 Creep deformation curves under constant stress loadings 


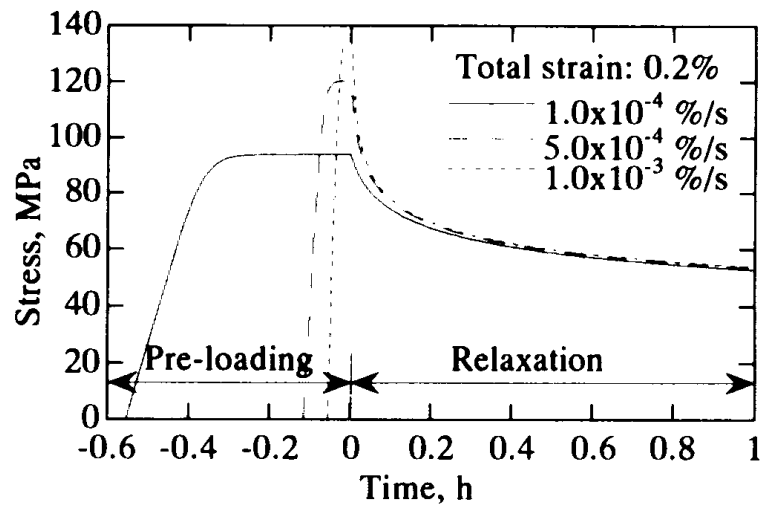

Fig. 8 The effect of pre loading on relaxation curves

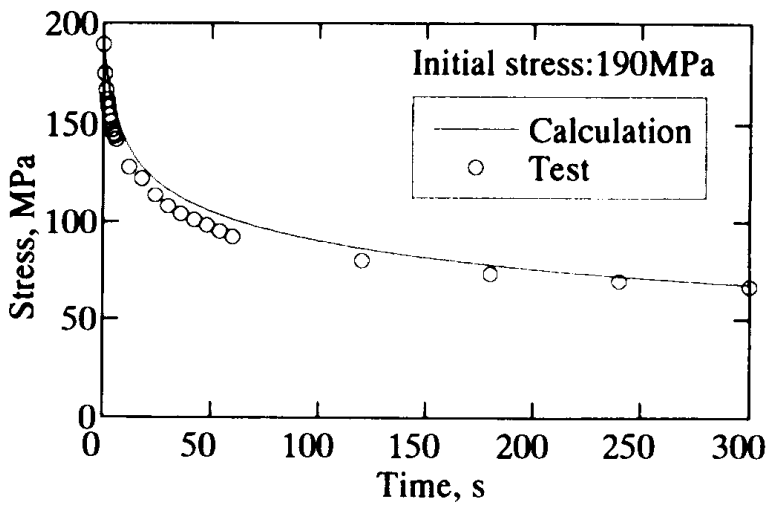

Fig. 9 Stress relaxation during a dwell period

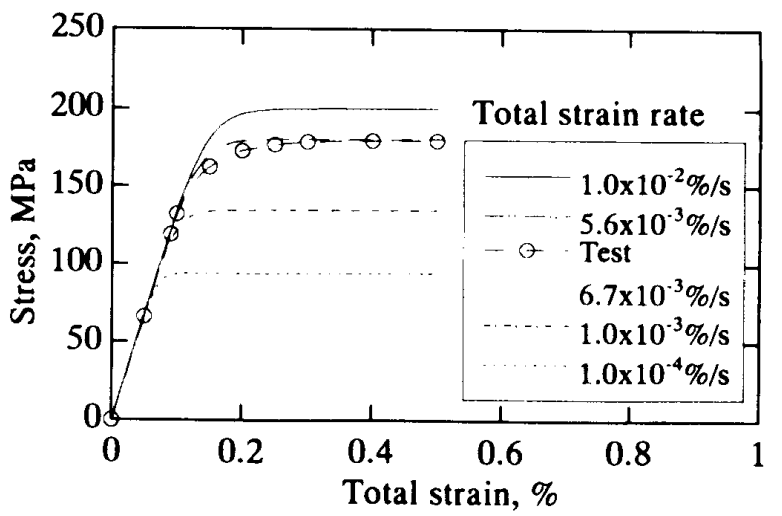

Fig. 10 Stress strain curves at various total strain rates

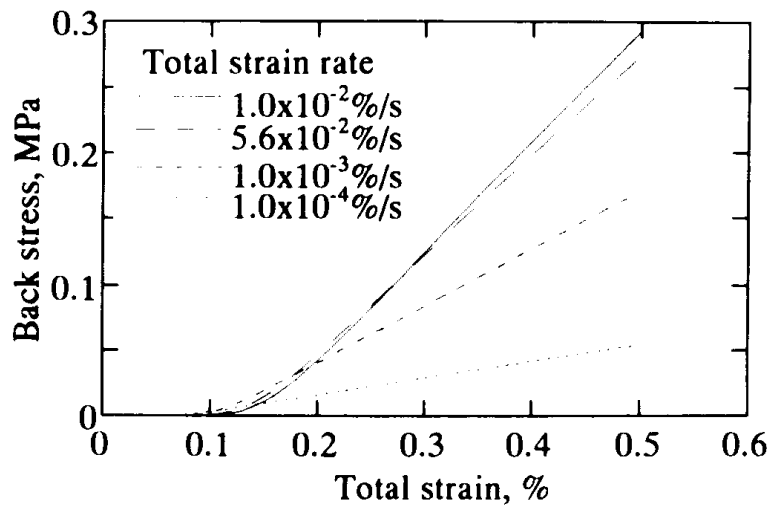

Fig. 11 Back stress developed during a loading at various total strain rates

$$
\dot{\sigma}=E\left[\dot{\varepsilon}_{t o t}-K\left\{\sigma-\left(\sigma_{b}+\rho\right)\right\}^{N}\right]
$$

\section{5. 解析結果と実験結果との比較}

定忍力クリープ変形 $(\sigma=58,90,120,170,200,250$ $\mathrm{MPa})$ の解析結果を図 $7(\mathrm{a}) \sim(\mathrm{f})$ に示す。一次十二次 クリープを記述する本構成式は，クリープ変形曲線を 精度良くシミュレーション可能なことがわかった。こ

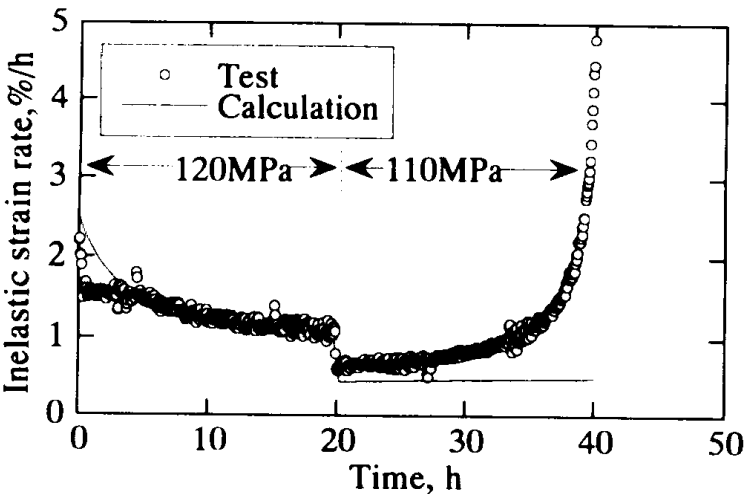

Fig. 12 Inelastic strain rate in stress dip test

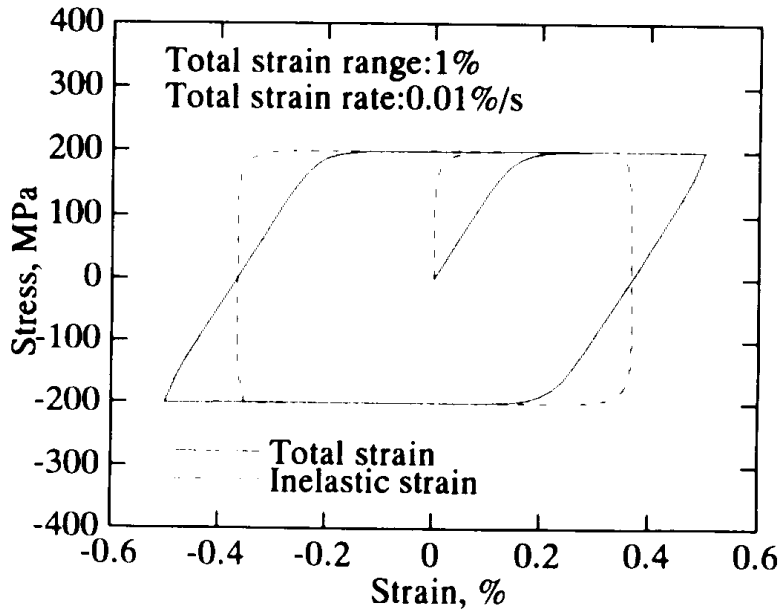

(a) Stress vs. strains

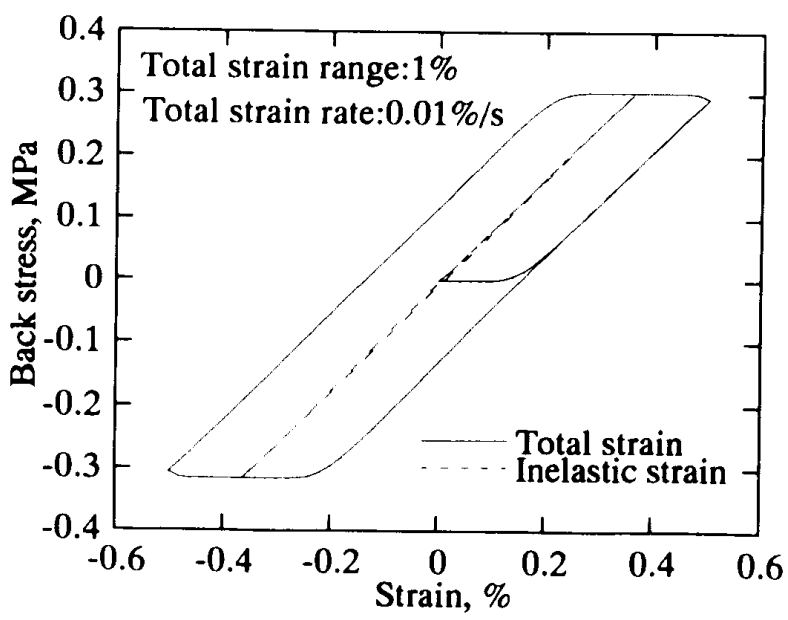

(b) Back stress vs. strains

Fig. 13 Stress-strain curves for a low cycle fatigue test 
れらの解析では式(11)の $\sigma_{b, \text { off }}$ を $\sigma_{b}$ の初期值として 式(13)の計算に用いている。

伈力緩和試験で全ひずみを一定に保持すると，弾性 ひずみが隇少し，非弾性ひずみが累積する。この緩和 挙動は，試験前の応力腹歷によって変化する初期応力， 内部応力に依存する。全ひずみが $0.2 \%$ に到達するま での全ひずみ速度の影響 $\left(1.0 \times 10^{-3} \sim 1.0 \times 10^{-4} \% / \mathrm{s}\right)$

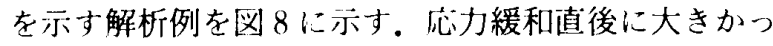
た応力履歴の影響は，時間の経過とともになくなるこ とがわかる。初期応力の值を実験結果と一致させて得 られた施力和曲線の)解析例(緩和時間 $=300 \mathrm{~s}$ )を図 9 に示す、材料モデルは緩和特性を良く表していること がおかる。

全ひずみ速度を一定にした引張変形の伈力一全ひず みの)解析例 $\left(1.0 \times 10^{-2} \sim 1.0 \times 10^{-4} \% / \mathrm{s}\right)$ を図 10 に示 古.ゲージ長さ $25 \mathrm{~mm}$ の丸棒試験片で得られた実験 值も亦してある。制御したクロスヘッド引張速度 0.1 $\mathrm{mm} / \mathrm{min}$ をひずみ速度に換算すると, $6.7 \times 10^{-3} \% / \mathrm{s}$ となるが、解析例の $5.6 \times 10^{-3} \% / \mathrm{s}$ とほほ致してい る。汹11 は背伈力の発展を示す。

伈力急堿試験(定応力クリープ試験の途中で，応力 を $120 \mathrm{MPa}$ から $110 \mathrm{MPa}$ に減少)の実験結果と解析 結果との比較を四 12 に示す。央験結果では, 応力変化 後まもなく㳄次クリーフ領域に入り変形速度が加速さ れているが，忍力急減後の非弾性ひずみ速度は解析結 果とほほ一致している。

低サイクル披労試験は引張変形試験と问じ荷重负荷 形成となるが，ひずみ速度の符査が反転する。低サイ クル披学曲線の解析例(全ひずみ範曲 $=1 \%$ ，ひずみ速 度 $=0.01 \% / \mathrm{s})$ を図 $13(\mathrm{a})$ ，( (b)に示寸。それぞれ応 力，背忍力と全ひずみ，非弾性ひずみの関係を表す。

\section{6. 結}

新しく提案した粘弹性モデルに基づき，定忍力クリ 一プ変形特性より材料走数を決定する非弾性構成式の
導出手順を示し，ハステロイ XR の構成式を定式化し た。この粘弾性材料モデルでは，内部応力は背応力と 摩擦力上り成り, 背忍力の速度はその現在值 $\sigma_{b}$ と $\sigma_{b}^{*}$ の差，並びにひずみ速度 $\dot{\varepsilon}^{*} に$ 独立に比例する。八 テロイXRのクリーナ変形、引張り，応力緩和，念力 急減試験に対する高温変形举動を解析した結果，本非 弹性構成式は，時間依存形の材料変形挙動を精度上く 記述できることを確認した。

\section{文献}

(1) Garofalo, F., Fundamentals of Crept and Crept $R$ upture in Metals, Macmillan. (1965), 16 17. New York

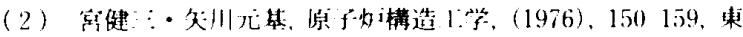
宗大学出版全

(3) Robinson, D. N., Nucl. Eng. De's., 83(1984), 389396

(4) Blass, J. J., Corum, J. M. and Chang. S. J., Proc of the Workshop on Structural Design Criteria for HTR, Jül Conf 71, (1989), 206224.

(5) Kaji, Y., Muto, Y. and Tachibana, T., Creep Behavior of Hastelloy XR2 at Very High Temperature, Proc. 5th Int. Conf. on Creep of Matorials. (1992), 101 109. Florida.

(6) Chaboche, J. L. and Rousselier. (j., On the Plastic and Viscoplastic Constitutive Equations Part I: Rules developed with internal variable concept. ASME PIT. $105(1983), 153164$

( 7 ) Miller, A., An Inelastic Constitutive Model for Monotonic, Cyclic, and Creep Deformation, Trans. ASME, J. Eng. Mater. Tochnol, 98(1976). 97113.

(8) Cernocky, E. P. and Krempl, E.. A Nonlinear Lnaxial Integral Constitutive Equation Incorporating Rate Effect. Creep and Relaxation, Int. J. Nonline'ar Mech. 14(1979), 183

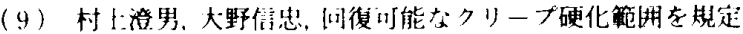

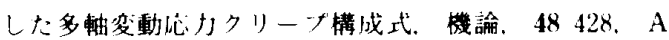
(1982), 431439.

（10）大野信恕，加智義文，村1:澄男，非線形硬化材料0)緙这し 整性棈成式，機論，51470。年(1985)，23492358.

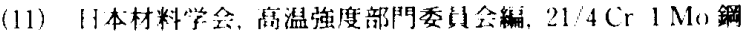

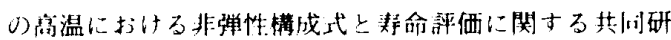
究第 I 部, (1986)、393-405.

(12) Riedel, H., Fracture at High Temperatures, (1986), 3 13. Springer Verlag.

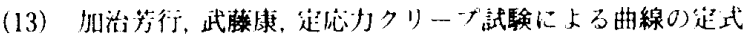
化, JAERI M 89 210. (1989). 